\title{
First evidence towards chemical self-recognition in a
}

2

3

4

5

6

8

9

9

\section{gecko}

Birgit Szabo*a, Eva Ringler ${ }^{a}$

a Division of Behavioural Ecology, Institute of Ecology and Evolution, University of Bern, Bern, Switzerland

*Correspond to: Birgit Szabo, Division of Behavioural Ecology, University of Bern, 3032 Bern,

Switzerland; email: birgit.szabo@gmx.at,

ORCID BS: 0000-0002-3226-8621

ORCID ER: 0000-0003-3273-6568

Author contribution: BS - Conceptualization; BS - Data curation; BS - Formal analysis; ER - Funding acquisition; BS - Investigation; BS - Methodology; BS - Project administration; ER Resources; ER - Supervision; BS - Validation; BS - Visualization; BS, ER - Roles/Writing original draft; BS, ER - Writing - review \& editing. 
bioRxiv preprint doi: https://doi.org/10.1101/2021.10.27.465717; this version posted October 29, 2021. The copyright holder for this preprint (which was not certified by peer review) is the author/funder, who has granted bioRxiv a license to display the preprint in perpetuity. It is made available under aCC-BY-NC-ND 4.0 International license.

RUNNING HEAD: Self-recognition in a gecko

\section{Abstract}

22

Self-recognition is the ability to recognise stimuli originating from oneself. Humans and most great apes show evidence of true self-recognition in the mirror test. They use their reflection to remove a mark that is only visible in the mirror. Not all animals, however, rely primarily on vision. In lizards, chemical cues are important in social interactions. A number of lizard species show chemical self-recognition but it has never been investigated in a gecko species. Here, we test the tokay gecko (Gekko gecko) a territorial species with parental care on their ability to discriminate their own skin and faecal chemicals from those of same-sex, unfamiliar conspecifics. Geckos show a higher response rate towards chemicals from unfamiliar individuals compared to self-produced chemicals and a water control. Lizards showed selfdirected behaviour, responded stronger to skin chemicals and females responded more than males. Our study provides first evidence towards self-recognition and for a social function of chemical present on faeces in tokay geckos but further tests are needed to confirm true selfrecognition. Tokay geckos are an excellent model species to investigate individual recognition to demonstrate more sophisticated social cognitive abilities than have previously been attributed to reptiles.

Keywords: chemical discrimination, cognition, communication, Gekko gecko, reptile, 
bioRxiv preprint doi: https://doi.org/10.1101/2021.10.27.465717; this version posted October 29, 2021. The copyright holder for this preprint (which was not certified by peer review) is the author/funder, who has granted bioRxiv a license to display the preprint in perpetuity. It is made available under aCC-BY-NC-ND 4.0 International license.

RUNNING HEAD: Self-recognition in a gecko

\section{Introduction}

42 Self-recognition is the ability to recognise cues that represent/ originate from oneself (visual images, olfactory cues, acoustic stimuli) (Gallup, 1970; Gallup et al., 2011; Platek et al., 2004). Research into self-recognition aims to uncover self-awareness (the ability to become the object of one's own attention) and its' emergence across humans and non-human animals (Gallup, 1970; Gallup et al., 2011). The method of choice is the mirror self-recognition (MSR) test. In this test, a subject is confronted with a mirror and provided with a mark that can only be seen using the reflection in the mirror. Confirmation of MSR occurs when the subject inspects the mark and attempts to remove it using their reflection (Gallup, 1970). Two important control conditions need to be implemented. First, an invisible mark has to be used to exclude that physical irritation caused by the mark itself or the process of marking is triggering the behaviour (Gallup, 1970). Second, a mark has to be applied in a spot that can be seen without the use of the mirror to confirm the subjects' motivation to remove marks in general (Gallup and Anderson, 2018). Humans and most great apes show MSR (Gallup, 1970; Gallup et al., 2011) while evidence in other species has led to controversial discussion (Gallup and Anderson, 2018; 2020).

Not all species primarily depend on their visual sense. This has led to the development of the sniff-test for self-recognition used in dogs whose primary sense is smell (Cazzolla Gatti, 2016). These studies have demonstrated that dogs discriminate between their own odour and that of conspecifics. They sniff the urine of unfamiliar dogs for longer than their own urine (Cazzolla Gatti, 2016; Horowitz, 2017). Furthermore, they sniff their own odour longer when it is modified than the modifier by itself (Horowitz, 2017). Nonetheless, some researchers have criticised these studies as not being a true equivalent to the MSR test because dogs do not show self-directed behaviour in the sniff-test which is an important criterion in the MSR test (Gallup and Anderson, 2018). Interestingly, chemical self-recognition tests are a fairly common test in lizards (Aguilar et al., 2009; Alberts, 1992; Aragón et al., 2001; Bull et al., 2000; Cooper, 1999; Graves and Halpern, 1991; López et al., 1997). Particularly one study in male desert iguanas (Dipsosaurus dorsalis) showed that these animals perform self-directed 
bioRxiv preprint doi: https://doi.org/10.1101/2021.10.27.465717; this version posted October 29, 2021. The copyright holder for this preprint (which was not certified by peer review) is the author/funder, who has granted bioRxiv a license to display the preprint in perpetuity. It is made available under aCC-BY-NC-ND 4.0 International license.

RUNNING HEAD: Self-recognition in a gecko

behaviour after detection of their own femoral gland sections but did not show this behaviour towards the secretions of unfamiliar males (Alberts, 1992). Following the critique voiced regarding the results in dogs, this study demonstrates more conclusive evidence for selfrecognition using chemicals in lizards.

Generally, reptiles rely strongly on chemicals (i.e. pheromones) when it comes to individual recognition, territoriality, social interactions and mate choice (Norris and Lopez, 2001). In lizards, pheromones might originate from the skin or specialised glands such as femoral glands which are most pronounced in males (Norris and Lopez, 2001). Many species also possess cloacal glands that deposit pheromones onto the faeces (Norris and Lopez, 2001). This is especially important in scat piling lizards which defecate repeatedly in the same location (Bull et al., 1999a). Similar to latrines in mammals (e.g. Green et al., 2015; King et al., 2017), these scat piles can have a social function by communicating, for example, territory ownership (Bull et al., 1999a; 1999b) and group identity (Bull et al., 2000; but see Shah et al., 2006). Lizards detect pheromones using tongue-flicks (TF), protrusions of the tongue forward towards a stimulus (e.g. on the ground or on a swab) to collect chemicals (Cooper, 1994), and generally show increased TF rates towards stimuli from unfamiliar conspecifics (e.g. Alberts, 1992; Aragón et al., 2001; Cooper et al., 1999; Graves and Halpern, 1991).

Discrimination of self-produced chemicals and chemicals produced by unfamiliar, same-sex conspecifics has never been shown in a gecko species although leopard geckos (Eublepharis macularius) discriminate sex based on pheromones (Cooper and Steele, 1997; Mason and Gutzke, 1990) and thick-tailed geckos (Nephrurus milii) recognise their own scats to add additional faecal matter (Carpenter and Duvall, 1995). Many gecko species scat pile which suggests either a communicative function aimed at conspecifics, an anti-predatory function to avoid detection of refuges or both (Bull et al., 1999a; Carpenter and Duvall, 1995). Here, we test the tokay gecko (Gekko gecko), a large (up to $185 \mathrm{~mm}$ Snout Vent Length), nocturnal, insectivorous, scat piling gecko species from tropical South-East Asia (Grossmann, 2006). The aims of this study were to 
bioRxiv preprint doi: https://doi.org/10.1101/2021.10.27.465717; this version posted October 29, 2021. The copyright holder for this preprint (which was not certified by peer review) is the author/funder, who has granted bioRxiv a license to display the preprint in perpetuity. It is made available under aCC-BY-NC-ND 4.0 International license.

RUNNING HEAD: Self-recognition in a gecko

96

97

98

99

100

101

102

103

104

105

106

107

108

109

110

111

112

113

114

115

116

117

118

119

120

121

(1) investigate if tokay geckos can discriminate between self-produced chemicals and chemicals produced by unfamiliar, same-sex conspecifics on cotton swabs (Cooper, 1998).

(2) We were also interested in finding out if chemicals originating from scats were as effective as chemicals originating from the skin as stimuli.

We predicted, that if geckos are able to recognize their own odour they would show lower responses towards their own odour than the conspecific odour (e.g. Alberts, 1992; Cooper et al., 1999; Graves and Halpern, 1991). If geckos are capable of self-recognition, we expected to find both stimulus directed and ground directed TFs as a sign of comparison between the two stimuli when confronted with their own and unfamiliar conspecific odour. We predicted, however, less ground directed responses when confronted with their own odour as it is familiar and can be recognised easier. We also predicted that faecal chemicals were as effective as skin chemicals in eliciting a response if scats had a communicative function.

\section{Methods}

Study animals, housing and husbandry

We tested 22 captive bred, adult tokay geckos, 10 males $(S V L$ range $=11.35-15.02 \mathrm{~cm})$ and 12 females $(S V L$ range $=11.29-13.72 \mathrm{~cm})$. Animals were acquired from different breeders across Europe and approximately 2-6 years old at the time of the study. Animals were naïve to the experimental procedure used in this study.

At our facility, geckos are kept singly in plastic terraria (females $-45 \mathrm{~L} \times 45 \mathrm{~B} \times 70 \mathrm{H}$ $\mathrm{cm}$; males $-90 \mathrm{~L} \times 45 \mathrm{~B} \times 100 \mathrm{H} \mathrm{cm}$ ). Enclosures are equipped with a drainage layer of clay pebbles and a layer of organic rainforest soil (Dragon BIO-Ground) on top separated by a mosquito mesh to prevent mixing of the layers. On the soil surface we spread autoclaved red oak leaves. Collembola, isopods and earth worms in the soil break down the faecal matter produced by the geckos. Each enclosure also includes a compressed cork back wall, cork 
bioRxiv preprint doi: https://doi.org/10.1101/2021.10.27.465717; this version posted October 29, 2021. The copyright holder for this preprint (which was not certified by peer review) is the author/funder, who has granted bioRxiv a license to display the preprint in perpetuity. It is made available under aCC-BY-NC-ND 4.0 International license.

RUNNING HEAD: Self-recognition in a gecko

branches, refuges made out of cork branches cut in half and hung on the back wall as well as plants.

Enclosures are located in a fully controlled environment with a reversed photo period.

Because tokay geckos are nocturnal, the dark cycle (when geckos are active) lasts from 6am

is equipped with an additional light to provide lizards with UVB (Exo Terra Reptile UVB 100, $25 \mathrm{~W})$ during the light cycle. The system automatically simulates a sunrise and sunset. Temperature is automatically control and reaches approximately $25^{\circ} \mathrm{C}$ during the night cycle and $31^{\circ} \mathrm{C}$ during the day cycle. To allow animals to thermoregulate, a heat mat (TropicShop) is fixed to the outside of each enclosure increasing the temperature by $\sim 5^{\circ} \mathrm{C}$. To simulate the tropical condition this species experiences in the wild, the room humidity is kept at $50 \%$ and daily rainfall (osmotic water, 30 s every $12 \mathrm{~h}$ at $5 \mathrm{pm}$ and $4 \mathrm{am}$ ) increases the humidity within enclosures to $100 \%$. Humidity decreases with time until the next rainfall event. All enclosures are set up on shelfs with small enclosures on the top and large enclosures on the bottom. Animals are spread evenly across two rooms. crickets (Acheta domesticus). Before feeding, crickets are gut loaded using cricket mix (reptile planet LDT), Purina Beyond Nature's Protein ${ }^{\mathrm{TM}}$ Adult dry cat food and fresh carrots to ensure that they provided optimal nutrition (Vitamin D and calcium). Each individual lizard receives 35 crickets each feeding with tweezers to be able to monitor the food intake. A water bowl provides water ad libitum. Once a month geckos are captured and weighed to ensure healthy weight.

Lizards were tested in their home enclosures to reduce stress of handling (Langkilde and Shine, 2006) between $10^{\text {th }}$ of August to $30^{\text {th }}$ September 2021. Testing was conducted under red light (PHILIPS TL-D 36W/15 RED). The light we use has a red component at $718 \mathrm{~nm}$ 
bioRxiv preprint doi: https://doi.org/10.1101/2021.10.27.465717; this version posted October $29,2021$. The copyright holder for this preprint (which was not certified by peer review) is the author/funder, who has granted bioRxiv a license to display the preprint in perpetuity. It is made available under aCC-BY-NC-ND 4.0 International license.

RUNNING HEAD: Self-recognition in a gecko

149 which is not detectable by the tokay geckos' photoreceptors (Loew 1994). Furthermore, a blue

150 UV-C component at $282 \mathrm{~nm}$ is also produced which is visible to the geckos (Loew 1994) and 151 promotes gecko activity (personal observation).

152 Because animals were spread across two rooms, each room was tested on a different, non-feeding day (either Tuesday or Thursday) once a week. Each individual was tested in a random order each day and the stimuli (control, own, same sex unfamiliar) and treatment (skin, faeces - i.e. scat) were also randomised across trials. As a positive control we used the odour of tap water on a paper towel. To create the control stimulus, one side of a cotton swab was taped 10 times on a moistened paper towel. As the familiar odour we used the individuals own odour either from their skin collected by gently rubbing one side of a cotton swab over its' back and/or sides 10 times or from a fresh (no older than 2 days) scat. The cotton swab was rubbed on the scat until a stain was visible. To create the same-sex unfamiliar stimulus we took chemicals from the skin or scats of a same sex individual from the second room. Although animals never had direct contact with each other within a room we were unsure if the smell of individuals could spread within a room. To ensure true unfamiliarity, we used the individuals from the second room located across a small hallway. The same methods as for collecting individuals own odour was used. Each individual was tested on their reaction towards the odour of three different same-sex conspecifics. From each conspecific both chemicals from skin and faeces were used to be able to compare the reaction across treatments while controlling for identity. All cotton swabs were marked at the back to indicate on which side the stimulus was applied. This was done so the experimenter could present each cotton swab with the stimulus facing downwards to exclude the use of visual information originating from faeces or UV-reflecting chemicals (Mason 1992). 
bioRxiv preprint doi: https://doi.org/10.1101/2021.10.27.465717; this version posted October 29, 2021. The copyright holder for this preprint (which was not certified by peer review) is the author/funder, who has granted bioRxiv a license to display the preprint in perpetuity. It is made available under aCC-BY-NC-ND 4.0 International license.

RUNNING HEAD: Self-recognition in a gecko

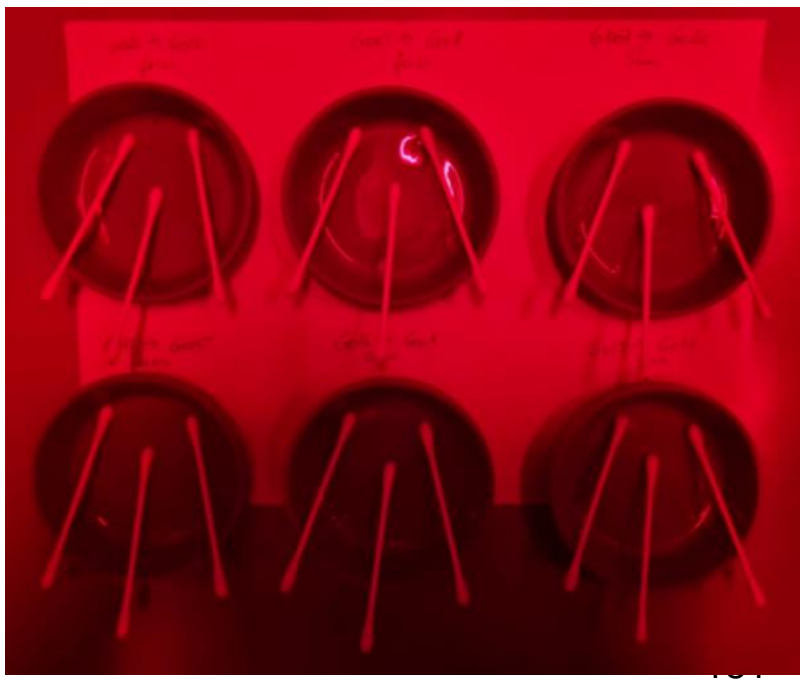

Figure 1. Setup of cotton swabs in clay bowls. For each focal subject swabs were placed in a separate clay bowl. Swabs were placed in the testing order. The experimenter made sure that swab tips covered in chemical stimuli never touched each other. To prevent excessive degradation of stimuli, individuals within a room were divided into two groups and the second group set up after the first group finished testing.

At the start of a test day stimuli were set up as follows: First, all swabs for the control were prepared. Next, all swabs with lizards own odour were prepared and lastly, all swabs with the unfamiliar odour were prepared. This was done to leave enough time (20-30 minutes) between stimulus collection and test of focal individuals to recover from stimulus collection (skin treatment). All swabs were placed in clay bowls in the order of presentation (Figure 1). We first set up half of the individuals, tested their reaction and then set up and tested the second half. This was done to prevent excessive degradation of chemical stimuli. After all individuals finished testing, cotton swabs were discarded and clay bowls thoroughly cleaned with hot water and a sponge. Then they were dried upside down until the next test day. The experimenter ensured that the inside of the bowls was never touched. Furthermore, they ensured that the cotton swabs within a bowl never touched.

After set up, we first tested all individuals with the first cotton swab, then all with the second and finally with the third. This was done to leave about 10-15 minutes between stimulus presentations and reduce carry-over effects between stimuli. Both males and females were tested using the same procedure. 
bioRxiv preprint doi: https://doi.org/10.1101/2021.10.27.465717; this version posted October 29, 2021. The copyright holder for this preprint (which was not certified by peer review) is the author/funder, who has granted bioRxiv a license to display the preprint in perpetuity. It is made available under aCC-BY-NC-ND 4.0 International license.

RUNNING HEAD: Self-recognition in a gecko

feeding and generally during testing. Next, we located an individual in its' enclosure. If the individual was hiding we gently removed the refuge from the back to expose it. Next, a cotton swab was presented holding it in a pair of $20 \mathrm{~cm}$ long metal tweezers. This ensured that the hand of the experimenter was far enough away to prevent the experimenters' odour interfering with the experiment. The experimenter was visible during trials similar as during regular feeding. Trials from the first two test days were recorded with a GoPro (Hero 5). However, videos were too dark and we had issues scoring the lizards behaviour. For all other trials we switched to recording with a Samsung S20 smartphone (108 Megapixel, 8K-FUHD) which produced far better quality videos under the light conditions. Furthermore, the ability to switch between front and back camera enabled us to take videos even when lizards were sitting above the tank entrance. By the second week of testing we detected a large decrease in bites likely caused by lizards learning that the cotton swab was not edible. We, therefore, decided to repeat the first trial at the end of the testing period to ensure that our measurements were not confounded by changes in behaviour.

Data collection

217 Videos were scored from the start of a trial, when the cotton swab was first presented within $2181 \mathrm{~cm}$ of the lizards snout. Trials lasted a maximum of 120 seconds (2 minutes). If a tongue 219 flick (TF) or bite occurred, the behaviour was video recorded for 60 s after the initial event following the procedure used in previous studies with squamates (e.g. Aragón et al., 2001; López et al., 1997; Martin et al. 2020). If the lizard showed a turn (whole body movement away from the swab, Table 1) and walked away from the swab the trial was terminated.

Videos were analysed blind as to which stimulus was presented but not to treatment which was visible in some videos. We used VLC media player (Version 3.0.7.1, Vetinari, Intel 64 bit) to score behaviour (Table 1) shown during trials. We scored bites, TF, breaths if the ventral side of the individual was visible (i.e. gular pumping, Norris and Lopez, 2011), deep breaths, and turns. TFs were divided into flicks directed at the stimulus (tongue tip aimed at the swab) and flicks directed towards the ground (tip aimed at the ground). We also measured 
bioRxiv preprint doi: https://doi.org/10.1101/2021.10.27.465717; this version posted October 29, 2021. The copyright holder for this preprint (which was not certified by peer review) is the author/funder, who has granted bioRxiv a license to display the preprint in perpetuity. It is made available under aCC-BY-NC-ND 4.0 International license.

RUNNING HEAD: Self-recognition in a gecko

the trial time in seconds starting from the time the stimulus was presented within $1 \mathrm{~cm}$ of the

lizards' snout until either 120 seconds without a bite or TF elapsed, the lizard performed a turn

or 60 seconds after the first bite or TF. Enclosure temperature was recoded automatically to

an accuracy of $0.1^{\circ} \mathrm{C}$ by the system responsible for regulating the environment within rooms.

234 Table 1. Ethogram of behaviours shown by tokay geckos in response to chemical stimuli.

\begin{tabular}{|l|l|}
\hline Name of behaviour & Description \\
\hline Breath & $\begin{array}{l}\text { One up and down movement of the lizards' throat = 1 breath. Only } \\
\text { visible from the ventral side. Recorded as counts. }\end{array}$ \\
\hline Deep breath & $\begin{array}{l}\text { One extension and retraction of the flanks behind the front legs. } \\
\text { Visible from the dorsal and ventral side. Recorded as counts. }\end{array}$ \\
\hline Tongue flick & $\begin{array}{l}\text { Quick protrusion of the tongue forward away from the mouth. NOT } \\
\text { licking of the lips which is also a protrusion of the tongue but along } \\
\text { the skin of the mouth. Recorded as counts. }\end{array}$ \\
\hline Bite & $\begin{array}{l}\text { The tip of the swab is taken between the upper and lower jaw. May } \\
\text { be accompanied by shaking of the head. Recorded as counts. }\end{array}$ \\
\hline Turn & $\begin{array}{l}\text { The lizards' moves away from the swab. The whole body moved } \\
\text { either past the swab, backwards away or involved a turn away } \\
\text { from the swab. Recoded as yes or no. A trial was terminated if this } \\
\text { behaviour was shown. }\end{array}$ \\
\hline
\end{tabular}

236 Ethical note

237 The test reported in this study are strictly non-invasive observations of behaviour. Introducing 238 odour of conspecifics is a practice used during enrichment in reptiles. We followed the 239 guidelines provided by the Association for the Study of Animal Behaviour/ Animal Behaviour 240 Society for the treatment of animals in behavioural research and Teaching (2018). All testing 241 was approved by the Suisse Federal Food Safety and Veterinary Office (National No. 33232, 242 Cantonal No. BE144/2020). Captive conditions were approved by the Suisse Federal Food 243 Safety and Veterinary Office (Laboratory animal husbandry license: No. BE4/11).

245 Statistical analysis

246 Power analysis

247 Before data collection, we performed a power analysis using $G^{*}$ power (Faul et al., 2007; 248 2009). As our study was designed as a $2 \times 2 \times 3$ factorial designed, we calculated power based 
bioRxiv preprint doi: https://doi.org/10.1101/2021.10.27.465717; this version posted October $29,2021$. The copyright holder for this preprint (which was not certified by peer review) is the author/funder, who has granted bioRxiv a license to display the preprint in perpetuity. It is made available under aCC-BY-NC-ND 4.0 International license.

RUNNING HEAD: Self-recognition in a gecko

on a within factor repeated measures ANOVA. The literature on chemical discrimination in other lizard and worm lizard species (Alberts,1992; Cooper et al., 1999; López et al., 1997) generally suggested large effect sizes. We were, however, unsure what effect size to expect from our geckos and therefore calculated the minimal effect size that could be reliably detected at a power of 0.8 . We specified an alpha level of 0.05 , a power of 0.8 , six groups with three measurements, a correlation among repeated measures of 0.5 and a correction of 1 . With these settings and a sample size of 24 individuals we are able to detect an effect size of 0.3 at an actual power of 0.99 . The sample size used in our study was 22 individuals. We expected, however, only a slight reduction in the actual power to detect a small effect size.

Data analysis

260 General reaction

We were interested if the reaction towards the presented stimuli was affected by the treatment (scat or skin), stimulus (water control, own or unfamiliar odour), sex (male or female), the order in which stimuli were presented, trial and temperature. These were used as fixed effects in three models looking at all tongue flicks produced in 60 seconds, deep breaths per second and breaths per second. For TFs we used a generalised linear mixed zero-inflation Poisson model (GLMM, package glmmTMB, Brooks et al., 2017) because our dataset included a large amount of 0 TFs. The conditional model included the above mentioned fixed effects while the zero-inflation model only included treatment, stimulus and sex as fixed effects. We did not expect all fixed effects to cause zero-inflation. Both the models included a random effect of animal identity to account for repeated measures. We were also interested if the difference in size between the test subject and the unfamiliar individual (delta SVL) from which the odour was taken affected TFs. To this end, we looked at TFs produced in the unfamiliar condition

273 only as the response variable in another zero-inflation Poisson model. Both the conditional 274 model and zero-inflation model included delta SVL and treatment as fixed effects and trial and 
bioRxiv preprint doi: https://doi.org/10.1101/2021.10.27.465717; this version posted October $29,2021$. The copyright holder for this preprint (which was not certified by peer review) is the author/funder, who has granted bioRxiv a license to display the preprint in perpetuity. It is made available under aCC-BY-NC-ND 4.0 International license.

RUNNING HEAD: Self-recognition in a gecko

animal identity as random effects. In both analyses we specified session for the overdispersion component.

For the two measures of breathing, we first divided the number of breaths by the trial time to get a comparable measure for the breaths (breaths and deep breaths per second). We used breaths and deep breaths per second as the response variable in linear mixed effects models (LME, package ImerTest, Kuznetsova et al., 2017) with Gaussian family including the above mentioned fixed effects. Both models conformed to the assumption of residual normality (visual inspection of qqplots). Both models included a random effect of animal identity and session to account for repeated measures. We did not analyse bites because they were shown too infrequent to be analysed.

Differences between swab and ground directed tongue flicks

Across all trials, males only tongue flicked three times while females together produced 202 TFs. We, therefore, based the following analysis on the data from females only. To identify if lizards compared their own odour to that of an unfamiliar individual we recorded TFs directed at the swab and those directed at the ground (on which their own odour was present). We analysed swab and ground directed TFs separately. We used generalised linear mixed zeroinflation Poisson models with ground or swab TFs as the response variable. The conditional models included stimulus as the only fixed effect as well as treatment, trial and animal identity as random effects. Treatment and trial were included as random effects because the general analysis revealed significant effects on TFs. In the zero-inflation models we used treatment and stimulus as fixed effects and animal identity as the random effect. We also specified session for the over-dispersion component. Finally, we also compared the two TFs within stimulus conditions using their average across trials and treatments (to avoid pseudoreplication) with Wilcoxon signed rank tests for paired data. 
bioRxiv preprint doi: https://doi.org/10.1101/2021.10.27.465717; this version posted October 29, 2021. The copyright holder for this preprint (which was not certified by peer review) is the author/funder, who has granted bioRxiv a license to display the preprint in perpetuity. It is made available under aCC-BY-NC-ND 4.0 International license.

RUNNING HEAD: Self-recognition in a gecko

303 Framework (OSF; link for review purposes:

304 https://osf.io/jp7h8/?view only=b4c0eac3792f4adaaef2ff6745aebf45)

305

306 Results

307 One female (G015) could not be tested as she was too anxious and was only used as a 308 stimulus individual. All other geckos habituated fast to being rubbed on their back with a swab 309 and did not flee during stimulus collection by the second week of testing (the first week of 310 testing was not used for analysis).

312 General reaction to the presented stimuli

313 Our analysis revealed that males tongue flicked much less than females (GLMM, estimate = $3144.249, z$-value $=-4.674, \mathrm{Cl}_{\text {low }}=-6.031, \mathrm{Cl}_{\text {up }}=-2.467, p$-value $<0.001 ;$ Figure $\left.2 \mathrm{~A}\right)$ and that 315 lizards tongue flicked less towards odour originating from scats than from skin (GLMM, 316 estimate $=-0.406, z$-value $=-2.413, \mathrm{Cl}_{\text {low }}=-0.736, \mathrm{Cl}_{\text {up }}=-0.076, p$-value $=0.016$, Figure 2B). 317 Compared to swabs containing the odour of unfamiliar individuals, lizards directed less TFs 318 towards tap water from a paper towel $\left(\mathrm{GLMM}\right.$, estimate $=-0.556, z$-value $=-2.733, \mathrm{Cl}_{\text {low }}=-$ $3190.954, \mathrm{Cl}_{\text {up }}=-0.157, p$-value $=0.006$; Figure $\left.2 \mathrm{~A}\right)$ and their own odour $(\mathrm{GLMM}$, estimate $=$ 320 $0.698, z$-value $=-3.562, \mathrm{Cl}_{\text {low }}=-1.083, \mathrm{Cl}_{\text {up }}=-0.314, p$-value $=0.0004 ;$ Figure $\left.2 \mathrm{~A}\right)$. Overall, lizards decreased TFs over the course of the experiment (GLMM, estimate $=-0.196, z$-value $322=-2.099, \mathrm{Cl}_{\text {low }}=-0.378, \mathrm{Cl}_{\text {up }}=-0.013, p$-value $\left.=0.036\right)$. We detected no effect of stimulus $323 \operatorname{order}\left(\mathrm{GLMM}\right.$, estimate $=0.043, z$-value $=0.481, \mathrm{Cl}_{\text {low }}=-0.133, \mathrm{Cl}_{\text {up }}=0.219, p$-value $\left.=0.631\right)$ 324 and temperature $\left(\mathrm{GLMM}\right.$, estimate $=0.086, z$-value $=0.277, \mathrm{Cl}_{\text {low }}=-0.524, \mathrm{Cl}_{\text {up }}=0.697, p$ 325 value $=0.782$ ) and the size of the stimulus individual had no effect on the number of TFs $326\left(\right.$ GLMM, estimate $=-0.123, z$-value $=-0.667, \mathrm{Cl}_{\text {low }}=-0.524, \mathrm{Cl}_{\text {up }}=0.697, p$-value $\left.=0.505\right)$. The zero-inflation models did not produce any significant results (GLMM, $p$-value > 0.05; Table $\mathrm{A} 1$ and $\mathrm{A} 2)$. 
bioRxiv preprint doi: https://doi.org/10.1101/2021.10.27.465717; this version posted October 29, 2021. The copyright holder for this preprint (which was not certified by peer review) is the author/funder, who has granted bioRxiv a license to display the preprint in perpetuity. It is made available under aCC-BY-NC-ND 4.0 International license.

RUNNING HEAD: Self-recognition in a gecko

We found no significant effects of any of the fixed effects on deep breaths per second

(LME, $p$-value $>0.05$, Table A3) but geckos showed a higher breathing rate in response to stimuli originating from scats (when responses towards all stimuli were lumped together) indicating a stronger involvement of olfaction ( $\mathrm{LME}$, estimate $=0.106, t$-value $=3.132, \mathrm{Cl}_{\text {low }}=$
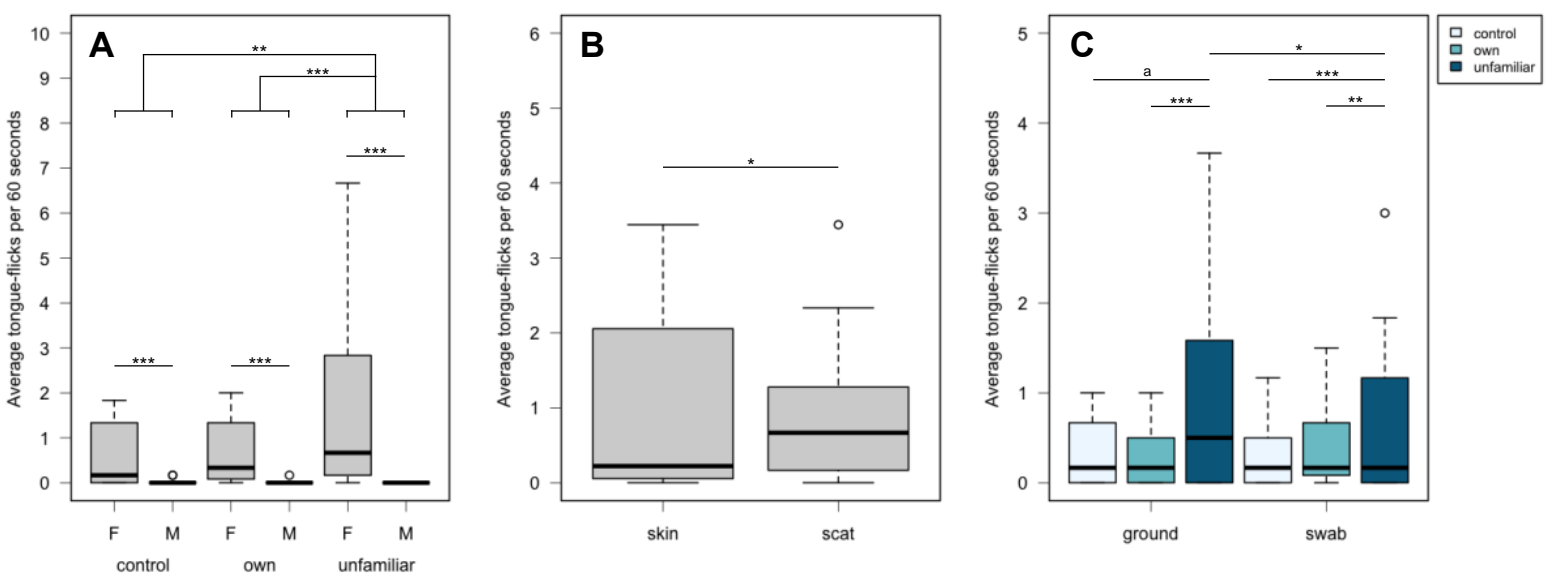

337 Figure 2. (A) Average tongue flicks produced within 60 seconds in the three stimulus conditions separated between males and females. Overall, lizards tongue flicked the most in the unfamiliar conditions and males tongue flicks less than females. (B) Average tongue flicks produced within 60 seconds across the skin and scat treatment. Lizards tongue flicked less in response to scats. (C) Average tongue flicks produced within 60 seconds directed towards the

342 ground and the swab separated into stimulus conditions. Only data from females are shown.

343 Females tongue flicked more when stimuli originated from unfamiliar individuals (dark blue) 344 compared to the own (medium blue) and control condition (light blue). Females tongue flicked 345 the ground more than the swab in the unfamiliar condition only. a $p<0.06,{ }^{*} p<0.05,{ }^{* *} p<$ $0.01,{ }^{* * *} p<0.001$. 
bioRxiv preprint doi: https://doi.org/10.1101/2021.10.27.465717; this version posted October 29, 2021. The copyright holder for this preprint (which was not certified by peer review) is the author/funder, who has granted bioRxiv a license to display the preprint in perpetuity. It is made available under aCC-BY-NC-ND 4.0 International license.

RUNNING HEAD: Self-recognition in a gecko

Differences between swab and ground directed tongue flicks

349 Females directed less ground TFs towards their own odour compared to odour from unfamiliar 350 individuals $\left(\mathrm{GLMM}\right.$, estimate $=-1.133, z$-value $=-3.872, \mathrm{Cl}_{\text {low }}=-1.707, \mathrm{Cl}_{\text {up }}=-0.560, p$-value $351=0.00011$, Figure 2C). Females also directed less swab TFs towards their own odour (GLMM, estimate $=-0.927, z$-value $=-2.979, \mathrm{Cl}_{\text {low }}=-1.538, \mathrm{Cl}_{\mathrm{up}}=-0.317, p$-value $=0.003$, Figure $2 \mathrm{C}$ ) and even less towards the water control $\left(\mathrm{GLMM}\right.$, estimate $=-1.405, z$-value $=-4.614, \mathrm{Cl}_{\text {low }}=$ $-2.002, \mathrm{Cl}_{\text {up }}=-0.808, p$-value $<0.001$, Figure $\left.2 \mathrm{C}\right)$. The zero-inflation models did not produce any significant results (GLMM, $p$-value $>0.05$, Table A5 and A6). Within conditions females directed more TFs towards the ground in the unfamiliar condition (Wilcoxon signed rank tests, $\mathrm{V}=3, \mathrm{~N}=11, p$-value $=0.012$, Figure $2 \mathrm{C}$ ). We found no differences in the control (Wilcoxon signed rank tests, $\mathrm{V}=18.5, \mathrm{~N}=11, p$-value $=0.801$, Figure $2 \mathrm{C}$ ) and own odour condition (Wilcoxon signed rank tests, $\mathrm{V}=14.5, \mathrm{~N}=11, p$-value $=0.829$, Figure $2 \mathrm{C}$ ).

360

\section{Discussion}

Our experiment demonstrated that, at least female tokay geckos, discriminate between their own odour and that of an unfamiliar female using chemicals originating from the skin and scats but they show a weaker response to chemicals originating from scats. More TFs occurred towards the odour of unfamiliar individuals and females produced more ground directed TFs in response to the unfamiliar conspecific odour. In general, lizards sampled the stimulus most (swab directed TFs) in the unfamiliar condition and we found no differences in TFs directed towards their own odour and the water control. chemical stimuli originating from unfamiliar, same-sex conspecifics. Our results are in line with

372 these studies but only in females. Males only tongue flicked a total of three times during the 373 course of the experiment. Either, males do not rely as strongly on skin and scat chemicals for 374 individual recognition or they show a delayed response which we did not record using our 
bioRxiv preprint doi: https://doi.org/10.1101/2021.10.27.465717; this version posted October 29, 2021. The copyright holder for this preprint (which was not certified by peer review) is the author/funder, who has granted bioRxiv a license to display the preprint in perpetuity. It is made available under aCC-BY-NC-ND 4.0 International license.

RUNNING HEAD: Self-recognition in a gecko

methodology. Indeed, we observed an increase in activity including TFs in some males after trials had ended. Male tokay geckos are territorial (Grossmann, 2006) and their behaviour

377 might be interpreted as searching for the intruder. It is, however, necessary to run additional 378 test recording not just the immediate response of males within two minutes but record behaviour for a longer time such as 10-15 minutes after stimulus presentation. Furthermore, males might react stronger to femoral gland secretions similar to male amphisbaenians (Blanus cinereus; Cooper et al., 1994) which should be tested in the future.

We also predicted that lizards would show chemical self-recognition by producing more ground directed TFs in response to the unfamiliar odour compared to their own odour. Our results confirm our prediction. Testing individuals inside their own enclosure posed an experimental advantage. Their enclosures are saturated with their own odour which made it possible to detect "self-directed" behaviour which would not have been possible in a neutral environment. Although male desert iguanas showed self-directed TFs towards their femoral glands (Alberts, 1992), we did not expect to find such behaviour in our geckos. Tokay geckos are, however, territorial, show site fidelity and scat pile. We expected, therefore, that if any comparison between the presented stimuli and self-produced odour did take place, this would likely be shown by TFs towards the ground. These ground directed TFs were very pronounced and easy to score because animals would always turn their heads away from the swab before tongue flicking the ground. Our results point towards similar difficulty to recognise tap water and their own scent because ground and swab directed TFs did not differ across these test conditions. They did differ in the unfamiliar condition. We recorded higher rates of ground directed TFs compared to swab directed TFs demonstrating a need for increased comparison with their own odour. Interestingly, a study in male lberian rock-lizards (Lacerta monticola) showed no differences in non-swab directed TF between males own and unfamiliar males femoral gland secretion (Aragón et al., 2001). This study tested wild caught males that were kept together with a second individual on their reaction to femoral gland secretions. We used chemical from skin and scats from captive bred individuals kept singly and mainly analysed

402 the reaction from females to these stimuli. It is possible that the scent of the second individual 
bioRxiv preprint doi: https://doi.org/10.1101/2021.10.27.465717; this version posted October $29,2021$. The copyright holder for this preprint (which was not certified by peer review) is the author/funder, who has granted bioRxiv a license to display the preprint in perpetuity. It is made available under aCC-BY-NC-ND 4.0 International license.

RUNNING HEAD: Self-recognition in a gecko

present in the enclosure interfered with "self-directed" TFs in rock-lizards. A comparison to our

results is, however, difficult due to the many differences between studies.

A next step towards more conclusive evidence for true self-recognition would be to test

geckos' reaction towards a change in their own odour similar to what was done with dogs

(Horowitz, 2017). Dogs are more interested in their own odour when it was marked but where

less interested in the mark alone. If geckos similarly increase ground directed TFs towards their marked odour compared to the mark alone then this would further support our geckos' ability to show true self-recognition.

Previous studies have considered that an increased rate of TFs towards the odour of unfamiliar individuals could be caused by novelty of the stimulus (Bull et al., 1999a; 2000).

413 Bull and colleagues (1999a; 2000) used chemical stimuli from heterospecific individuals that were unfamiliar to the test lizards as a control. If novelty was causing increased TF rates then lizards would also show an increased response towards the heteropsecifics' odour which they did not ruling out novelty as a cause for increased TF rates (Bull et al., 1999a; 2000). In our study, we used tap water from a paper towel as a control instead of odourless deionised water which elicited a lower rate of TFs compared to the unfamiliar odour. The fact that similar numbers of TFs (ground and swab directed) were directed towards their own odour and the odour of tap water and a paper towel shows that novelty was not solely responsible for our lizards' reaction. As tap water and paper towels are not odourless, we would expect increased TF rates to inspect the novel odour which we did not find. We acknowledge, however, that an additional control similar to what was used in previous studies (Bull et al., 1999a; 2000) is needed to completely rule our novelty as a cause for the strong effect we found. Furthermore, we can also rule out that diet differences caused the difference in response towards own and unfamiliar odour because all our lizards were fed the same diet. produced less TFs towards scats this difference was small. Additional research could determine if geckos inspect scat piles of other individuals when available, if they are more

430 likely to defecate in locations with their own scat present (Carpenter and Duvall, 1995), and 
bioRxiv preprint doi: https://doi.org/10.1101/2021.10.27.465717; this version posted October 29, 2021. The copyright holder for this preprint (which was not certified by peer review) is the author/funder, who has granted bioRxiv a license to display the preprint in perpetuity. It is made available under aCC-BY-NC-ND 4.0 International license.

RUNNING HEAD: Self-recognition in a gecko

could investigate if lipids are deposited on scats by glands (Bull et al., 1999b). Furthermore,

432 scat piling might have a possible function related to predator avoidance when predators use 433 the odour of scats to locate refuges (Bull et al., 1999a; Carpenter and Duvall, 1995; Norris and 434 Lopez, 2011). Studies on wild lizards should document the location of scat piles to determine 435 if scat piles have an anti-predator function as well. Scat piles in locations that are not frequently visited by geckos would point towards an anti-predator function.

In summary, we provide fist evidence for chemical self-recognition in a gecko species and a possible social function of scat piles. Further investigations are, however, needed to confirm true self-recognition in tokay geckos and to better understand the communicative

440 function of scats. Future studies could also look at other forms of recognition such as

441 discrimination between familiar and unfamiliar individuals, mate recognition and kin 442 recognition of skin, femoral gland and scat odours. Tokay geckos are a good model species 443 to investigate recognition in general as they show biparental care and form temporary family 444 groups with their offspring (Grossmann, 2006; Somma, 2003). Such studies can potentially 445 demonstrate more sophisticated social cognitive abilities than have previously been attributed 446 to reptiles (Doody et al., 2013).

\section{Acknowledgements}

449 This work was supported by the University of Bern, the Austrian Science Fund (FWF) [grant 450 P 31518, PI: ER] and the Swiss National Science Foundation (SNSF) [grant 197921, PI: ER]. 451 We would like to thank Eva Barbara Zwygart for her support with animal husbandry. 
bioRxiv preprint doi: https://doi.org/10.1101/2021.10.27.465717; this version posted October 29, 2021. The copyright holder for this preprint (which was not certified by peer review) is the author/funder, who has granted bioRxiv a license to display the preprint in perpetuity. It is made available under aCC-BY-NC-ND 4.0 International license.

RUNNING HEAD: Self-recognition in a gecko

\section{References}

454

455

456

457

458

459

460

461

462

463

464

465

466

467

468

469

470

471

472

473

474

475

476

477

478

Alberts, A. C. (1992). Pheromonal Self-Recognition in Desert Iguanas. Copeia, 1992(1), 229-232.

Aguilar, P. M., Labra, A., \& Niemeyer, H. M. (2009). Chemical self-recognition in the lizard Liolaemus fitzgeraldi. Journal of Ethology, 27(1), 181-184. doi:10.1007/s10164-0080088-x

Aragón, P., López, P., \& Martín, J. (2001). Discrimination of Femoral Gland Secretions from Familiar and Unfamiliar Conspecifics by Male Iberian Rock-Lizards, Lacerta monticola. Journal of Herpetology, 35(2), 346-350.

Brooks, M. E., Kristensen, K., van Benthem, K. J., Magnusson, A., Berg, C. W., Nielsen, A., Skaug, H. J., Maechler, M., \& Bolker, B. M. (2017). glmmTMB balances speed and flexibility among packages for zero-inflated generalized linear mixed modeling. The $R$ Journal, 9(2), 378-400.

Bull, C. M., Griffin, C. L., \& Johnston, G. R. (1999a). Olfactory discrimination in scat-piling lizards. Behavioral Ecology, 10(2), 136-140.

Bull, C. M., Griffin, C. L., Lanham, E. J., \& Johnston, G. R. (2000). Recognition of Pheromones from Group Members in a Gregarious Lizard, Egernia stokesii. Journal of Herpetology, 34(1), 92-99.

Bull, C. M., Griffin, C. L., \& Perkins, M. V. (1999b). Some properties of a pheromone allowing individual recognition from the scats of an Australian lizard, Egernia striolata. Acta Ethologica, 2, 35-42.

Carpenter, G. C., \& Duvall, D. (1995). Fecal Scent Marking in the Western Banded Gecko (Coleonyx variegatus). Herpetologica, 51(1), 33-38.

Cazzolla Gatti, R. (2016). Self-consciousness: beyond the looking-glass and what dogs found there. Ethology Ecology \& Evolution, 28(2), 232-240.

doi:10.1080/03949370.2015.1102777 
bioRxiv preprint doi: https://doi.org/10.1101/2021.10.27.465717; this version posted October 29, 2021. The copyright holder for this preprint (which was not certified by peer review) is the author/funder, who has granted bioRxiv a license to display the preprint in perpetuity. It is made available under aCC-BY-NC-ND 4.0 International license.

RUNNING HEAD: Self-recognition in a gecko

479 Cooper, W. E., Jr. (1994). Chemical discrimination by tongue-flicking in lizards: A review with hypotheses on its' origin and its' ecological and phylogenetic relationship. Journal of Chemical Ecology, 20(2), 439-487.

483

Cooper, W. E., Jr. (1998). Evaluation of swab and related tests as a bioassay for assessing responses by Squamate reptiles to chemical stimuli. Journal of Chemical Ecology, 24(5), 841-866.

Cooper, W. E., Jr., López, P., \& Salvador, A. (1994). Pheromone detection by an amphisbaenian. Animal Behaviour, 47, 1401-1411.

488

Cooper, W. E., Jr., \& Steele, L. J. (1997). Pheromonal discrimination of sex by male and 489 female leopard geckos (Eublepharis macularius). Journal of Chemical Ecology, 23, 2967-2977.

Cooper, W. E., Jr, Van Wyk, J. H., \& Mouton, P. L. F. N. (1999). Discrimination between selfproduced pheromones and those produced by individuals of the same sex in the lizard Cordylus cordylus. Journal of Chemical Ecology, 25(1), 197-208.

Doody, J. S., Burghardt, G. M., \& Dinets, V. (2013). Breaking the social-non-social dichotomy: A role for reptiles in vertebrate social behavior research? Ethology, 119(2), 95-103.

Faul, F., Erdfelder, E., Lang, A.-G., \& Buchner, A. (2007). G*Power 3: A flexible statistical power analysis program for the social, behavioral, and biomedical sciences. Behavior Research Methods, 39, 175-191.

Faul, F., Erdfelder, E., Buchner, A., \& Lang, A.-G. (2009). Statistical power analyses using Methods, 41, 1149-1160.

Gallup, G. G., Jr. (1970). Chimpanzees: self-recognition. Science, 167, 86-87. to demonstrate self-recognition in non-primate species. Behavioural Processes, 148, 16-19. doi:10.1016/j.beproc.2017.12.010 
bioRxiv preprint doi: https://doi.org/10.1101/2021.10.27.465717; this version posted October 29, 2021. The copyright holder for this preprint (which was not certified by peer review) is the author/funder, who has granted bioRxiv a license to display the preprint in perpetuity. It is made available under aCC-BY-NC-ND 4.0 International license.

RUNNING HEAD: Self-recognition in a gecko

Gallup, G. G., Jr., \& Anderson, J. R. (2020). Self-recognition in animals: Where do we stand 50 years later? Lessons from cleaner wrasse and other species. Psychology of Consciousness: Theory, Research, and Practice, 7(1), 46-58.

Gallup, G. G., Jr., Anderson, J. R., \& Platek, S. M. (2011). Self-recognition. In S. Gallagher (Ed.), The Oxford Handbook of the Self (pp. 80-110). New York: Oxford University Press.

Graves, B. M., \& Halpern, M. (1991). Discrimination of self from conspecific chemical cues in Tiliqua scincoides (Sauria: Scincidae). Journal of Herpetology, 25(1), 125-126.

Green, M. L., Monick, K., Manjerovic, M. B., Novakofski, J., \& Mateus-Pinilla, N. (2015). Communication stations: cameras reveal river otter (Lontra canadensis) behavior and activity patterns at latrines. Journal of Ethology, 33, 225-234.

Grossmann, W. (2006). Der Tokeh, Gekko gecko. Münster: Natur und Tier Verlag.

Guidelines for the treatment of animals in behavioural research and teaching (2018). Animal Behaviour, 135, I-X. https://doi.org/10.1006/anbe.1996.0293

Horowitz, A. (2017). Smelling themselves: Dogs investigate their own odours longer when modified in an "olfactory mirror" test. Behavioural Processes, 143, 17-24. doi:10.1016/j.beproc.2017.08.001

King, T. W., Salom-Pérez, R., Shipley, L. A., Quigley, H. B., \& Thornton, D. H. (2017). Ocelot latrines: communication centers for Neotropical mammals. Journal of Mammalogy, 98(1), 106-113.

Kuznetsova, A., Brockhoff, P. B., \& Christensen, R. H. B. (2017). ImerTest Package: Tests in Linear Mixed Effects Models. Journal of Statistical Software, 82(13), 1-26. doi: 10.18637/jss.v082.i13

Langkilde, T., \& Shine, R. (2006). How much stress do researchers inflict on their study animals? A case study using a scincid lizard, Eulamprus heatwolei. Journal of Experimental Biology, 209, 1035-1043. doi:10.1242/jeb.02112 
bioRxiv preprint doi: https://doi.org/10.1101/2021.10.27.465717; this version posted October 29, 2021. The copyright holder for this preprint (which was not certified by peer review) is the author/funder, who has granted bioRxiv a license to display the preprint in perpetuity. It is made available under aCC-BY-NC-ND 4.0 International license.

RUNNING HEAD: Self-recognition in a gecko

534 López, P., Salvador, A., \& Cooper Jr, W. E. (1997). Discrimination of self from other males by chemosensory cues in the amphisbaenian (Blanus cinereus). Journal of Comparative Psychology, 111(1), 105-109.

Mason, R. T. (1992). Reptilian Pheromones. In C. Gans \& D. Crews (Eds.), Biology of the Reptilia Physiology E (pp. 114-228). Chicago and London: The University Of Chicago Press.

Mason, R. T., \& Gutzke, W. H. N. (1990). Sex recognition in the leopard gecko, Eublepharis macularius (Sauria: Gekkonidae). Possible mediation by skin-derived semiochemicals. Journal of Chemical Ecology, 16, 27-36.

Norris, D. O., \& Lopez, K. H. (2011). Homones and Reproduction of Vertebrates (Vol. 3 Reptiles). UK: Academic Press.

Platek, S. M., Burch, R. L., \& Gallup, G. G. (2001). Sex differences in olfactory selfrecognition. Physiology \& Behavior, 73, 635-640.

Platek, S. M., Thomson, J. W., \& Gallup, G. G., Jr. (2004). Cross-modal self-recognition: the role of visual, auditory, and olfactory primes. Conscious Cognition, 13(1), 197-210. doi:10.1016/j.concog.2003.10.001

R Development Core Team (2020). R: a language and environment for statistical computing. http://www.R-project.org. Accessed January 2021

Shah, B., Hudson, S., \& Shine, R. (2006). Social aggregation by thick-tailed geckos (Nephrurus milii, Gekkonidae): does scat piling play a role? Australian Journal of Zoology, 54, 271-275. 
bioRxiv preprint doi: https://doi.org/10.1101/2021.10.27.465717; this version posted October 29, 2021. The copyright holder for this preprint (which was not certified by peer review) is the author/funder, who has granted bioRxiv a license to display the preprint in perpetuity. It is made available under aCC-BY-NC-ND 4.0 International license.

RUNNING HEAD: Self-recognition in a gecko

\section{Appendix}

560

561 Results tables

562

563 Table A1. Parameter estimates and test statistics for the generalised linear mixed zero-

564 inflation Poisson model looking at all tongue flicks produced by all tested individuals. The

565 models included a random effect of animal identity and an over-dispersion parameter of

566 session. Significant results are highlighted in bold. $\mathrm{Cl}$ - confidence interval.

\begin{tabular}{|c|c|c|c|c|c|}
\hline \multicolumn{6}{|c|}{ Conditional model } \\
\hline Parameter & Estimate & z-value & $\mathrm{Cl}_{\text {low }}$ & Clup & $p$-value \\
\hline Intercept & -1.924 & -0.239 & -17.681 & 13.833 & 0.811 \\
\hline Scat & -0.406 & -2.413 & -0.736 & -0.076 & 0.016 \\
\hline Water control & -0.556 & -2.733 & -0.954 & -0.157 & 0.006 \\
\hline Own odour & -0.698 & -3.562 & -1.083 & -0.314 & 0.0004 \\
\hline Male & -4.249 & -4.674 & -6.031 & -2.467 & $2.95^{\star} 10^{-6}$ \\
\hline Stimulus order & 0.043 & 0.481 & -0.133 & 0.219 & 0.631 \\
\hline Trial & -0.196 & -2.099 & -0.378 & -0.013 & 0.036 \\
\hline Temperature & 0.086 & 0.277 & -0.524 & 0.697 & 0.782 \\
\hline \multicolumn{6}{|c|}{ Zero-inflation model } \\
\hline Parameter & Estimate & $z$-value & $\mathrm{Cl}_{\text {low }}$ & $\mathrm{Cl}_{\text {up }}$ & $p$-value \\
\hline Intercept & -1.462 & -1.083 & -4.107 & 1.184 & 0.279 \\
\hline Scat & -1.959 & -1.820 & -4.069 & 0.151 & 0.069 \\
\hline Water control & 1.393 & 1.282 & -0.737 & 3.523 & 0.200 \\
\hline Own odour & 0.469 & 0.450 & -1.574 & 2.511 & 0.653 \\
\hline Male & -17.667 & -0.003 & 0.554 & 5.785 & 0.998 \\
\hline
\end{tabular}


bioRxiv preprint doi: https://doi.org/10.1101/2021.10.27.465717; this version posted October 29, 2021. The copyright holder for this preprint (which was not certified by peer review) is the author/funder, who has granted bioRxiv a license to display the preprint in perpetuity. It is made available under aCC-BY-NC-ND 4.0 International license.

RUNNING HEAD: Self-recognition in a gecko

568 Table A2. Parameter estimates and test statistics for the generalised linear mixed zero569 inflation Poisson model looking at all tongue flicks produced in the unfamiliar condition by all 570 tested individuals. The models included trial and animal identity as random effects. Significant 571 results are highlighted in bold. $\mathrm{Cl}$ - confidence interval.

\section{Conditional model}

572

\begin{tabular}{|c|c|c|c|c|c|}
\hline Parameter & Estimate & z-value & Cliow & Clup & $p$-value \\
\hline Intercept & -2.662 & -2.233 & -4.998 & -0.325 & 0.026 \\
\hline Scat & -0.318 & -1.405 & -0.761 & 0.126 & 0.160 \\
\hline Delta SVL & -0.123 & -0.667 & -0.485 & 0.239 & 0.505 \\
\hline \multicolumn{6}{|c|}{ Zero-inflation model } \\
\hline Parameter & Estimate & $z$-value & $\mathrm{Cl}_{\text {low }}$ & $\mathrm{Cl}_{\text {up }}$ & $p$-value \\
\hline Intercept & -1.518 & -1.817 & -3.155 & 0.119 & 0.069 \\
\hline Scat & -0.158 & -0.143 & -2.314 & 1.998 & 0.886 \\
\hline Delta SVL & -0.662 & -1.490 & -1.533 & 0.209 & 0.136 \\
\hline
\end{tabular}


bioRxiv preprint doi: https://doi.org/10.1101/2021.10.27.465717; this version posted October 29, 2021. The copyright holder for this preprint (which was not certified by peer review) is the author/funder, who has granted bioRxiv a license to display the preprint in perpetuity. It is made available under aCC-BY-NC-ND 4.0 International license.

RUNNING HEAD: Self-recognition in a gecko

574 Table A3. Parameter estimates and test statistics for the linear mixed model looking at deep

575 breaths per second. The model included session and animal identity as random effects. $\mathrm{Cl}-$

576 confidence interval.

577

\begin{tabular}{|l|r|r|r|r|r|r|}
\hline Parameter & \multicolumn{1}{|l|}{ Estimate } & \multicolumn{1}{l|}{$\boldsymbol{d f}$} & \multicolumn{1}{l|}{-value } & \multicolumn{1}{l|}{ Cl low } & \multicolumn{1}{l|}{ Clup } & $\boldsymbol{p}$-value \\
\hline Intercept & 0.489 & 35.2 & 0.352 & -2.142 & 3.112 & 0.727 \\
\hline Scat & 0.015 & 315.8 & 0.559 & -0.036 & 0.065 & 0.576 \\
\hline Water control & 0.023 & 315.3 & 0.727 & -0.038 & 0.085 & 0.468 \\
\hline Own odour & -0.005 & 315.5 & -0.151 & -0.066 & 0.057 & 0.880 \\
\hline Male & 0.108 & 18.9 & 1.879 & -0.004 & 0.219 & 0.076 \\
\hline Stimulus order & -0.019 & 315.4 & -1.191 & -0.050 & 0.012 & 0.235 \\
\hline Trial & -0.025 & 39.0 & -1.117 & -0.070 & 0.023 & 0.271 \\
\hline Temperature & -0.006 & 35.1 & -0.118 & -0.108 & 0.096 & 0.907 \\
\hline
\end{tabular}


bioRxiv preprint doi: https://doi.org/10.1101/2021.10.27.465717; this version posted October 29, 2021. The copyright holder for this preprint (which was not certified by peer review) is the author/funder, who has granted bioRxiv a license to display the preprint in perpetuity. It is made available under aCC-BY-NC-ND 4.0 International license.

RUNNING HEAD: Self-recognition in a gecko

579 Table A4. Parameter estimates and test statistics for the linear mixed model looking at breaths

580 per second. The model included a random intercept of animal identity and a random slope of

581 session. Significant results are highlighted in bold. $\mathrm{Cl}$ - confidence interval.

582

\begin{tabular}{|l|r|r|r|r|r|r|}
\hline Parameter & \multicolumn{1}{|l|}{ Estimate } & \multicolumn{1}{l|}{$\boldsymbol{l}$ df } & \multicolumn{1}{l|}{-value } & \multicolumn{1}{l|}{ Cl low } & \multicolumn{1}{l|}{ Clup } & \multicolumn{1}{l|}{-value } \\
\hline Intercept & 0.124 & 111.9 & 0.099 & -2.296 & 2.514 & 0.921 \\
\hline Scat & $\mathbf{0 . 1 0 6}$ & $\mathbf{1 5 4 . 7}$ & $\mathbf{2 . 1 3 2}$ & $\mathbf{0 . 0 3 9}$ & $\mathbf{0 . 1 7 0}$ & $\mathbf{0 . 0 0 2}$ \\
\hline Water control & 0.044 & 142.9 & 1.163 & -0.030 & 0.116 & 0.247 \\
\hline Own odour & 0.020 & 140.7 & 0.512 & -0.055 & 0.096 & 0.610 \\
\hline Male & 0.008 & 19.1 & 0.143 & -0.094 & 0.113 & 0.888 \\
\hline Stimulus order & -0.013 & 137.8 & -0.686 & -0.050 & 0.024 & 0.494 \\
\hline Trial & -0.032 & 59.2 & -1.418 & -0.077 & 0.014 & 0.162 \\
\hline Temperature & 0.033 & 112.2 & 0.684 & -0.059 & 0.127 & 0.496 \\
\hline
\end{tabular}


bioRxiv preprint doi: https://doi.org/10.1101/2021.10.27.465717; this version posted October 29, 2021. The copyright holder for this preprint (which was not certified by peer review) is the author/funder, who has granted bioRxiv a license to display the preprint in perpetuity. It is made available under aCC-BY-NC-ND 4.0 International license.

RUNNING HEAD: Self-recognition in a gecko

584 Table A5. Parameter estimates and test statistics for the generalised linear mixed zero-

585 inflation Poisson model looking at all ground tongue flicks across stimulus conditions in

586 females. The conditional model included treatment, trial and animal identity as random effects,

587 the zero-inflation model included animal identity as the random effect. Significant results are

588 highlighted in bold. $\mathrm{Cl}$ - confidence interval.

589

\begin{tabular}{|c|c|c|c|c|c|}
\hline \multicolumn{6}{|c|}{ Conditional model } \\
\hline Parameter & Estimate & $z$-value & $\mathrm{Cl}_{\text {low }}$ & $\mathrm{Cl}_{\text {up }}$ & $p$-value \\
\hline Intercept & -1.064 & -1.239 & -2.746 & 0.618 & 0.215 \\
\hline Water control & -0.637 & -1.899 & -1.294 & 0.021 & 0.058 \\
\hline Own odour & -1.133 & -3.872 & -1.707 & -0.560 & 0.0001 \\
\hline \multicolumn{6}{|c|}{ Zero-inflation model } \\
\hline Parameter & Estimate & $z$-value & Cliow & Clup & $p$-value \\
\hline Intercept & -1.463 & -1.157 & -3.942 & 1.016 & 0.247 \\
\hline Scat & -1.693 & -1.621 & -3.739 & 0.354 & 0.105 \\
\hline Water control & 1.998 & 1.680 & -0.333 & 4.329 & 0.093 \\
\hline Own odour & 0.240 & 0.203 & -2.069 & 2.548 & 0.839 \\
\hline
\end{tabular}


bioRxiv preprint doi: https://doi.org/10.1101/2021.10.27.465717; this version posted October 29, 2021. The copyright holder for this preprint (which was not certified by peer review) is the author/funder, who has granted bioRxiv a license to display the preprint in perpetuity. It is made available under aCC-BY-NC-ND 4.0 International license.

RUNNING HEAD: Self-recognition in a gecko

591 Table A6. Parameter estimates and test statistics for the generalised linear mixed zero-

592 inflation Poisson model looking at all swab tongue flicks across stimulus conditions in females.

593 The conditional model included treatment, trial and animal identity as random effects, the zero-

594 inflation model included animal identity as the random effect. Significant results are highlighted

595 in bold. $\mathrm{Cl}$ - confidence interval.

\begin{tabular}{|c|c|c|c|c|c|}
\hline \multicolumn{6}{|c|}{ Conditional model } \\
\hline Parameter & Estimate & $z$-value & $\mathrm{Cl}_{\text {low }}$ & $\mathrm{Cl}_{\text {up }}$ & $p$-value \\
\hline Intercept & -0.483 & -0.838 & -1.613 & 0.647 & 0.402 \\
\hline Water control & -1.405 & -4.614 & -2.002 & -0.808 & $3.96^{*} 10^{-6}$ \\
\hline Own odour & -0.927 & -2.979 & -1.538 & -0.317 & 0.003 \\
\hline \multicolumn{6}{|c|}{ Zero-inflation model } \\
\hline Parameter & Estimate & $z$-value & Cllow & Clup & $p$-value \\
\hline Intercept & -1.018 & -0.895 & -3.249 & 1.213 & 0.371 \\
\hline Scat & 1.912 & 1.597 & -0.435 & 4.259 & 0.110 \\
\hline Water control & -21.217 & -0.002 & -16347.2 & 16304.9 & 0.998 \\
\hline Own odour & -1.809 & -1.445 & -4.262 & 0.645 & 0.148 \\
\hline
\end{tabular}

